\title{
Relationships between a Thiol-Disulfide System and Liposoluble Antioxidants with Cytogenetic Indices in Humans Exposed to Low Doses Radiation
}

\author{
G. F. Ivanenko, E. B. Burlakova \\ Russian Academy of Sciences, Emanuel Institute of Biochemical Physics, Moscow, Russia \\ Email: galiv@sky.chph.ras.ru, seren@sky.chph.ras.ru
}

Received October 2012

\begin{abstract}
This work presents the results of biochemical examination of people exposed to irradiation as a result of the Chernobyl catastrophe. In remote period ( in 4, 5, 6 and 7 years) after Chernobyl accident we studied the state of the redox system of glutathione(GSH, GSSG) and the response of the system of essential lipid antioxidants (vitamin E, A) in blood plasma of people of various ages. An analysis of correlations between cytogenetic indices in lymphocytes and levels of reduced glutathione and liposoluble antioxidants in the plasma of peripheral blood in children born after the Chernobyl accident and liquidators is presented. The cumulative doses for the examined group of children received by their mothers from 0.8 to $70 \mathrm{cSv}$ and liquidators received, on average, the highest irradiation doses from 0.1 to $150 \mathrm{cSv}$. A complex relationship between lipo-and water-soluble antioxidants level in plasma in human population (children living in radionuclide-contaminated regions and the Chernobyl liquidators) exposed to chronic low-level radiation after the Chernobyl accident was demonstrated. The obtained experimental data indicate different responses of the human population water-and fat-soluble antioxidants system to low (from 0.1 to $20 \mathrm{cSv}$ ) and high (from 20 to $150 \mathrm{cSv}$ ) doses of ionizing radiation.
\end{abstract}

Keywords: Antioxidant; Radiation; Plasma; Human Population

\section{Introduction}

A large number of new facts concerning the effect of low-level radiation on living organisms were provided after the Chernobyl accident. The significance of lowdose exposures for cell survival, tissue damage, and individual health are poorly understood [1,2]. For a long period of nuclear industry development, exposures to low doses were considered safe. However, recent publications demonstrate a relatively high efficiency of lowlevel radiation in the region of low radiation doses. Active mutation process in various cells and tissues and carcinogenesis promotion were observed after exposure to low radiation doses [3]. Mutagenesis is accompanied by chromosomal and genomic instability in cells of various tissues. In the case of ionizing radiation, the primary damage, namely double-strand breaks, induced both structural chromosomal aberrations and microstructural DNA damage detected as gene mutations [4].

Various biochemical and biophysical tests are being developed in order to evaluate the effect of exposure to low radiation doses; in particular, the antioxidant status of the body is given considerable attention. Glutathione is particularly important among water-soluble antioxi- dants $[5,6]$. Resistance of the body to ionizing radiation depends on both lipid antioxidant activity and the level of sulfhydryl groups $[7,8]$.

It is common knowledge that thiols as well as vitamins $\mathrm{C}, \mathrm{A}$, and $\mathrm{E}$ protect cells from oxidation and inhibit lipid peroxidation. A relatively high contribution of watersoluble antioxidants is commonly associated with regeneration. Glutathione was proposed to mediate the reduction of at least two vitamins, $\alpha$-tocopherol and ascorbic acid; it increases their effect and prevents lipid peroxidation $[9,10]$.

Below we present experimental data on the effect of low-level radiation on the status of water-and lipo-soluble antioxidant in the liquidators and people living in conditions of long-term exposure to low radiation doses in the regions contaminated by radionuclides after the Chernobyl accident $\left(1-20 \mathrm{Ci} / \mathrm{km}^{2}\right)$. We tried to establish the relationship between levels of glutathione, vitamin E, $A$ and the level of radiation burden and to analyze the dose-response relationships for certain types of genetic damages such as the frequency chromatid breaks, in the course of long-term monitoring. Below we analyze possible correlations between cytogenetic indices in peri- 
pheral blood lymphocytes, glutathione and lipid antioxidant levels in blood plasma of people after the Chernobyl accident.

\section{Methods and Subjects}

Children were examined from birth to the age of eight in three regions with different levels of soil pollution with radionuclides (largely ${ }^{137} \mathrm{Cs}$ ) after the Chernobyl accident. Children $(n=125)$ from the Chechersk Region (15 - 20 $\mathrm{Ci} / \mathrm{km}^{2}$ ) (Gomel Region of Belorussia) were examined 5 years after the accident; after six years children $(n=210)$ from the Mtsensk Region ( 1 - $5 \mathrm{Ci} / \mathrm{km}^{2}$ ) and, after seven years, children $(n=116)$ from the Bolkhov Region (5 $10 \mathrm{Ci} / \mathrm{km}^{2}$ ) (both Orlov Region of Russia) were examined. Children at the age of $5-6-7$ years (at the moment of examination) survived the accident during their intrauterine development; other ones were born after the accident (1990-1992).

Four years after the Chernobyl accident (1986), we examined the liquidators (LI) that were working in the first days after the accident and later moved to Slavutich town outside the $30 \mathrm{~km}$ zone $(\mathrm{n}=22)$. The radiation doses of this group ranged from 2 to $150 \mathrm{cSv}$. Six years later, we examined one more group of liquidators (L2, n = 128) who worked from May 1986 to 1987 in the region of Chernobyl accident and received radiation doses from 0.1 to $70 \mathrm{cSv}$. Were examined children at the age 2 - 12 $(n=9)$ and of adults of Slavutich $(n=29)$ living in radionuclide-contaminated regions $\left(1-5 \mathrm{Ci} / \mathrm{km}^{2}\right)$. Residents of Moscow $(n=21)$ not exposed to radiation were the comparison group.

The level of reduced and oxidized glutathione in plasma was determined as described elsewhere [11,12] with modifications. Glutathione level was determined in 20 $100 \mu$ l plasma by spectrofluorometry at $350 / 420 \mathrm{~nm}$. The level of oxidized glutathione was calculated as the difference between the total numbers of SH groups before and after the reduction using blank assays and standard curves for GSH and GSSG. All results averaged for three parallel experiments were expressed as $\mu \mathrm{M}$. Tocopherol and retinol were determined by spectrofluorometry at 295/325 and 330/470 nm, respectively, with appropriate standards as described [13].

The cytogenetic test relied on the traditional method (analysis of unstable chromosomal aberrations). Whole blood $(0.5 \mathrm{ml})$ was cultivated as described by [14]. Both chromosomal (dicentrics, centric rings, and paired fragments) and chromatid (single fragments) aberrations were evaluated. The frequency of chromatid breaks (FCB) calculated as a sum of single fragments (Fs), doubled paired fragments (Fp), quadrupled dicentrics (Dc), and rings $(\mathrm{Cr})$ per 100 metaphases.

Individual radiation doses of the Chernobyl liquidators were determined as a total Chernobyl radiation loading. Individual accumulated doses of radiation were determined from the age of children or as a total Chernobyl radiation burden of their mothers before delivery. We studied the effect of accumulated radiation dose of mothers (Dm) after the Chernobyl accident on individual cytogenetic and biochemical changes in peripheral blood of their children.

\section{Results and Discussion}

Table presents the mean level of water-and lipo-soluble antioxidants (GSH, vitamins $\mathrm{E}$ and $\mathrm{A}$ ), oxidized glutathione in blood plasma of adults and children living in uncontaminated and radionuclide-contaminated regions after the Chernobyl accident $\left(1-20 \mathrm{Ci} / \mathrm{km}^{2}\right.$ by $\left.{ }^{137} \mathrm{Cs}\right)$ as well as of the liquidators with the radiation doses from 2 to 150 and from 0.1 to $70 \mathrm{cSv}$ (groups LI and L2, respectively). Table demonstrates the absence of significant differences in the studied indices in children and adults living in regions with different radionuclide contamination. Only the liquidators (LI) had a significantly lower GSH and a significantly higher level of GSSG in the blood plasma as compared to all studied residents (Table 1). However, the stability of the blood plasma indices in children from Mtsensk (1 - $\left.5 \mathrm{Ci} / \mathrm{km}^{2}\right)$, Bolkhov (5 - 10 $\left.\mathrm{Ci} / \mathrm{km}^{2}\right)$, and Chechersk $\left(15-20 \mathrm{Ci} / \mathrm{km}^{2}\right)$ with different levels of soil contamination by radionuclides was considerably lower as compared to people from uncontaminated regions. The $\chi^{2}$ test demonstrated that GSH level follows the Poisson distribution. Poisson variables have particularly high coefficients of variation (CV).

Table 1 shows that the CV exceeds $40 \%$ for GSH in children living in these regions. The highest individual variability was observed in children from the Chechersk region with the highest radionuclide contamination (15 $20 \mathrm{Ci} / \mathrm{km}^{2}$ ); the corresponding $\mathrm{CV}$ reflecting variability of the indices was equal to $82 \%$ for $\mathrm{GSH}$ and $67 \%$ for vitamin A. Levels of tocopherol and retinol in children from Chechersk region was significantly lower than in residents of uncontaminated regions. In addition to lipoperoxidative stress, children of Chechersk had a three times higher levels of GSSG in the blood plasma in comparison to Mtsensk and of Bolkhov residents (Table 1).

Apparently, the high individual variability of the studied indices in children depends on radiobiological properties of ionizing radiation in case of long-term exposure of their mothers to low-level radiation. We studied the effect of accumulated total radiation doses of mothers (Dm) after the Chernobyl accident on long-term changes of biochemical and cytogenetic indices in their children in comparison with the dose effects in the Chernobyl liquidators. 
Table 1. Mean plasma levels of reduced, oxidized glutathione, tocopherol and retinol in children and adults living in uncontaminated and radionuclide-contaminated regions [Mean \pm SEM (SD)].

\begin{tabular}{|c|c|c|c|c|}
\hline \multicolumn{5}{|c|}{ Children } \\
\hline & Mtsensk, 1 - $5 \mathrm{Ci} / \mathbf{k m}^{2}$ & Bolkhov, 5 - $10 \mathrm{Ci} / \mathbf{k m}^{2}$ & Chechersk, 15 - $20 \mathrm{Ci} / \mathrm{km}^{2}$ & Slavutich, 1 - $5 \mathrm{Ci} / \mathrm{km}^{2}$ \\
\hline Age, years & $1.7 \pm 0.1$ & $3.0 \pm 0.2$ & $0.8 \pm 0.1$ & $6.3 \pm 0.8$ \\
\hline $\mathrm{GSH}, \mu \mathrm{M}$ & $20.5 \pm 0.7(10.3)$ & $18.6 \pm 0.9(9.6)$ & $21.1 \pm 1.6(17.4)$ & $16.0 \pm 2.3(6.9)$ \\
\hline $\mathrm{n}$ & 218 & 116 & 125 & 9 \\
\hline Min - Max & $4.8-61.6$ & $5.0-57.4$ & $1.6-101.7$ & $4.9-28.1$ \\
\hline $\mathrm{CV}, \%$ & 50 & 52 & 82 & 43 \\
\hline GSSG, $\mu \mathrm{M}$ & $11.3 \pm 0.4(5.9)$ & $9.9 \pm 0.4(4.1)$ & $32.1 \pm 1.3(14.7)$ & $44.2 \pm 6.6$ (19.7) \\
\hline $\mathrm{n}$ & 210 & 116 & 120 & 9 \\
\hline Min - Max & $0.8-38.6$ & $1.4-22.7$ & $3.3-69.4$ & $17.0-70.3$ \\
\hline $\mathrm{CV}, \%$ & 52 & 41 & 46 & 45 \\
\hline Vitamin E, $\mu \mathrm{M}$ & $9.0 \pm 0.3(4.5)$ & $21.4 \pm 0.9(7.8)$ & $8.3 \pm 0.4(4.2)$ & $8.4 \pm 0.8(2.4)$ \\
\hline $\mathrm{n}$ & 198 & 67 & 120 & 9 \\
\hline Min - Max & $0.7-45.6$ & $7.3-37.8$ & $0.7-27.9$ & $4.9-12.6$ \\
\hline $\mathrm{CV}, \%$ & 50 & 36 & 51 & 29 \\
\hline Vitamin $\mathrm{A}, \mu \mathrm{M}$ & $0.9 \pm 0.03(0.5)$ & $2.4 \pm 0.1(1.2)$ & $0.9 \pm 0.1(0.6)$ & $2.0 \pm 0.2(0.5)$ \\
\hline $\mathrm{n}$ & 197 & 67 & 117 & 9 \\
\hline Min - Max & $0.2-5.7$ & $0.6-5.8$ & $0.1-3.4$ & $1.5-3.9$ \\
\hline $\mathrm{CV}, \%$ & 55 & 50 & 67 & 25 \\
\hline \multicolumn{5}{|c|}{ Adults } \\
\hline & Liquidators 1, 2 - 150 cSv & Liquidators 2, 0.1 - $70 \mathrm{cSv}$ & Slavutich 1 - 5 Ci/km² & Moscow \\
\hline Age, years & $42.0 \pm 1.8$ & $45.6 \pm 1.0$ & $40.7 \pm 2.4$ & $39.2 \pm 2.7$ \\
\hline $\mathrm{GSH}, \mu \mathrm{M}$ & $15.8 \pm 1.2(5.8)$ & $24.8 \pm 0.9(9.7)$ & $33.4 \pm 2.9(15.4)$ & $19.4 \pm 1.6(7.4)$ \\
\hline $\mathrm{n}$ & 22 & 128 & 29 & 21 \\
\hline Min - Max & $6.9-26.5$ & $6.7-55.2$ & $13-68.6$ & $11.2-40.0$ \\
\hline $\mathrm{CV}, \%$ & 37 & 39 & 46 & 38 \\
\hline GSSG, $\mu \mathrm{M}$ & $30.9 \pm 1.5(7.3)$ & $16.8 \pm 1.0(8.8)$ & $40.4 \pm 1.8(9.7)$ & $13.4 \pm 1.5(6.3)$ \\
\hline $\mathrm{n}$ & 22 & 81 & 29 & 19 \\
\hline Min - Max & $16.7-44.6$ & $3.6-54.2$ & $19.3-61.9$ & $5.5-27.1$ \\
\hline $\mathrm{CV}, \%$ & 24 & 52 & 24 & 47 \\
\hline Vitamin $\mathrm{E}, \mu \mathrm{M}$ & $22.7 \pm 1.2(5.7)$ & $19.4 \pm 0.7(7.2)$ & $13.6 \pm 1.1(5.6)$ & $22.3 \pm 1.6(7.4)$ \\
\hline $\mathrm{n}$ & 22 & 120 & 29 & 21 \\
\hline Min - Max & $15.0-39.0$ & $5.1-39.5$ & $7.2-30.1$ & $8.1-40.5$ \\
\hline $\mathrm{CV}, \%$ & 25 & 37 & 41 & 33 \\
\hline Vitamin $\mathrm{A}, \mu \mathrm{M}$ & $3.5 \pm 0.3(1.2)$ & $2.9 \pm 0.1(1.2)$ & $2.6 \pm 0.2(1.2)$ & $2.9 \pm 0.2(0.7)$ \\
\hline $\mathrm{n}$ & 22 & 120 & 29 & 21 \\
\hline Min - Max & $1.8-5.9$ & $0.5-7.9$ & $1.1-6.9$ & $2.0-4.4$ \\
\hline $\mathrm{CV}, \%$ & 34 & 41 & 46 & 24 \\
\hline
\end{tabular}

Figures 1(a)-(e) present the dose dependence levels water-and lipo-soluble antioxidants (GSH, tocopherol, retinol), oxidized glutathione in the plasma as well as the frequencies of chromatid breaks in peripheral blood lymphocytes of children living in Mtsensk (with radionuclide contamination of the soil within $1-5 \mathrm{Ci} / \mathrm{km}^{2} ; \mathrm{n}=$
35), Bolkhov (5 - $10 \mathrm{Ci} / \mathrm{km}^{2} ; \mathrm{n}=26$ ), and Chechersk (15 - $20 \mathrm{Ci} / \mathrm{km}^{2} ; \mathrm{n}=31$ ) as well as of the LI liquidators that worked in the first days after the accident $(\mathrm{n}=22)$ and the L2 liquidators $(\mathrm{n}=128)$ that worked from May 1986 to 1987 in the region of the Chernobyl accident with total radiation doses from 0.1 to $150 \mathrm{cSv}$. 

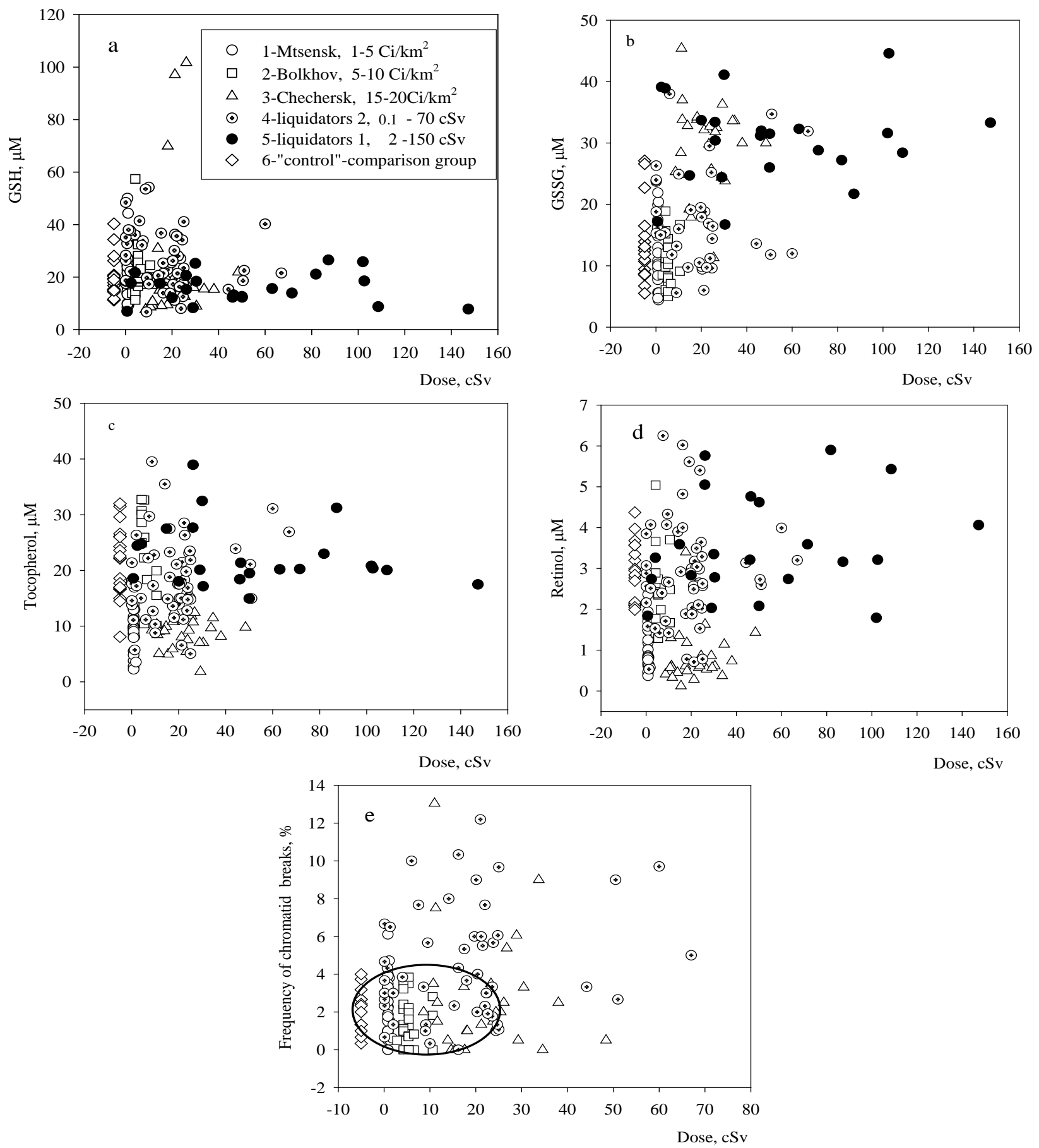

Figure 1. Relationship between total radiation exposure, plasma levels of reduced (a) and oxidized (b) glutathione, tocopherol (c), retinol (d), frequencies of chromatid breaks (e) in peripheral blood lymphocytes in children living in regions with different radionuclide contamination as well as in the Chernobyl liquidators (individual indices): 1-Mtsensk, 1 - 5 Ci/km²; 2-Bolkhov, 5 $10 \mathrm{Ci} / \mathrm{km}^{2}$; 3-Chechersk, 15 - $20 \mathrm{Ci} / \mathrm{km}^{2}$; 4-liquidators 1,2 - $150 \mathrm{cSv}$; 5-liquidators 2, 0.1 - $70 \mathrm{cSv}$; 6-“control”-comparison group. In Figure 1(e), there is marked a range of examined individuals with levels of frequencies of chromatid breaks which correspond with the level of "control".

Note that radiation burden of mothers living in the most radionuclide-contaminated Chechersk region (0.8 $60 \mathrm{cSv}$ ) were similar to those of the L2 liquidators (0.1 $70 \mathrm{cSv}$ ) who had worked in the region of the Chernobyl accident. The pattern of the relationship was similar. The level of reduced glutathione in the plasma increased in certain individuals exposed to doses below $20 \mathrm{cSv}$ and decreased for the doses from 20 to $60 \mathrm{cSv}$ (Figure 1(a)) 
Further increase in the radiation burden to 20 - $150 \mathrm{cSv}$ increased GSSG level in the plasma (Figure l(b)) and decreased GSH level in the plasma (Figure I(a)), which decreased the glutathione potential. Decreased levels of reduced glutathione under the influence of low-level radiation (below $20 \mathrm{cSv}$ ) is accompanied by accelerated consumption of vitamin E (Figure 1(c)) and increased level of vitamin A in blood plasma (Figure 1(d)). The deficiency of lipo-and water-soluble antioxidants revealed long after the accident (4 - 7 years) in the liquidators and children of exposed mothers is an important health marker for populations exposed to chronic low-level in radiation. The system of water- and liposoluble antioxidants differently responses to radiation exposure of low intensity depending on the exposure dose of radiation.

Different responses to the studied systems in human population to the effect of low-level radiation can be due to an increased sensitivity of the systems to radiation resulting from disturbed control mechanisms involving free radicals. High stationery concentrations of active oxygen forms at the low doses confirm proposed "delay" of the repairer systems [15]. Low efficiency of the repairer systems increase the level of spontaneous chromosomal disturbances, which induce mutations in genes and increase the incidence of cancer [16].

This conclusion is confirmed by an increase in cytogenetic disturbances in lymphocytes of peripheral blood determined upon an individual examination of this group of people (children and liquidators). Figure 1(e) presents the individual dose dependence of the frequencies of chromatid breaks in peripheral blood lymphocytes of children (Mtsensk, 1 - $5 \mathrm{Ci} / \mathrm{km}^{2}$; Bolkhov, 5 - $10 \mathrm{Ci} / \mathrm{km}^{2}$; and Chechersk, $15-20 \mathrm{Ci} / \mathrm{km}^{2}$ ) living in regions with different levels of radionuclide contamination of the soil after the Chernobyl accident as well as of liquidators 2, ( 0.1 to $70 \mathrm{cSv}$.) These experiments demonstrate the complex dependence of the frequencies of chromatid breaks in lymphocytes in human population on radiation doses. For instance, at low radiation doses (from 0.8 to $30 \mathrm{cSv}$ ), some individuals have a considerably increased frequencies of chromatid breaks (up to 12 per 100 cells; Figure $\mathbf{1 ( e ) ) ~ i n ~ l y m p h o c y t e s ~ a s ~ c o m p a r e d ~ t o ~ t h o s e ~ i n ~ p e o p l e ~ n o t ~}$ exposed to ionizing radiation. A two-or three-fold increase in the cytogenetic indices is observed in over $20 \%$ people at low radiation doses. When the doses increased from 30 to $60 \mathrm{cSv}$, the frequencies of chromatid breaks in peripheral blood lymphocytes also increased (up to 5 per 100 cells; Figure 1(e)). A 3 - 5-fold deviation of individual cytogenetic and biochemical indices from the control (Figure 1) indicates a high rate of mutations in somatic cells of children and L2 even after a long period after the accident ( 5 - 7 years). This fact can be considered as an epidemiological confirmation of the role of chromosomal aberrations in carcinogenesis, since the

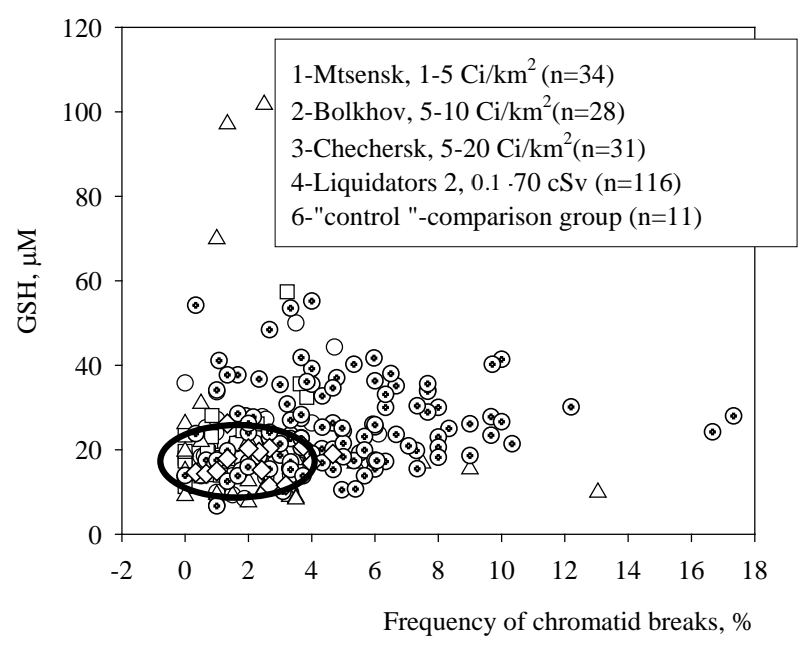

Figure 2. Relationship between frequencies of chromatid breaks in peripheral blood lymphocytes and plasma levels of reduced glutathione, in children living in regions with different radionuclide contamination as well as in the Chernobyl liquidators 2 (individual indices). In Figure 2, there is marked a range of examined individuals with levels of frequencies of chromatid breaks and levels GSH of people which correspond with the level of "control".

risk of cancer increases in individuals with high level of spontaneous chromosomal aberrations [16].

It was substantiated the studies of antioxidant status and role of cytogenetic examinations for predicting of the delayed consequences of irradiation. The development of various biochemical and the cytogenetic tests are of great importance for evaluation and prediction of individual radiosensitivity of the organism.

As an example, let us present data on the correlation between cytogenetic indices in peripheral blood lymphocytes and plasma levels GSH of people exposed to low doses of radiation (Figure 2). We observed unidirectional and bidirectional changes frequencies of chromatid breaks and biochemical indices of human blood (positive and negative correlation).

Quantitatively different response of the body to low (below $20 \mathrm{cSv}$ ) and high (from 20 to $150 \mathrm{cSv}$ ) doses of ionizing radiation is an unbiased marker of radiationinduced disorders and underlies development of far disorders in human population. To the great probability, the low-rate radiation possesses another mechanism compared with high doses of acute radiation.

\section{REFERENCES}

[1] W. F. Morgan and J. L. Schwartz, "Environmental Mutagen Society Symposium on Risks of Low Dose, Low Dose Rate Exposures of Ionizing Radiation to Humans," International Journal of Radiation Biology, Vol. 83, 2007, pp. 491-499.

http://dx.doi.org/10.1080/09553000701370886 
[2] A. V. Akleev "Tissue Reaction under Chronic Exposure to Ionizing Radiation,” Radiation Biology. Radioecology (Russian), Vol. 49, No. 1, 2009, pp. 5-20.

[3] N. E. A. Crompton, "Programmed Cell Response to Ionizing Radiation Damage,” Acta Oncologica, Vol. 37, 1998, pp. 129-142.

http://dx.doi.org/10.1080/028418698429685

[4] R. D. Govorun, “Cytogenetic Damage and Mutagenesis in Mammalian and Human Cells Induced by Ionizing Radiation with Varying LET,” Radiation Biology. Radioecology (Russian), Vol. 37, No. 4, 1997, pp. 539-548.

[5] J. Glavind, “Antioxidants in Animal Tissue,” Acta Chemica Scandinavica, Vol. 17, 1963, pp. 1635-1640. http://dx.doi.org/10.3891/acta.chem.scand.17-1635

[6] V. V. Sokolovskii, “A Thiol-Disulfide System in n Organism Reaction to Environmental Factors,” Nauka, SanktPeterburg, 2008, p. 111.

[7] E. B. Burlakova A. V. Alesenko, E. M. Molochkina, N. P. Palmina and N. G. Khrapova, "Biological Antioxidants in Radiation Damage and Malignant Growth,” Nauka, Moscow, 1975, p. 211.

[8] G. F. Ivanenko, "The Role of Antioxidant Activity of Lipids and Endogenous Thiols in Radio Resistance of the Organism,” Extended Abstract of Cand. Set (Biol.) Dissertation, Moscow, 1985, p. 168.

[9] D. D. M. Wayner, G. W. Burton, K. U. Ingold, L. R. C. Barclay and S. J. Locke "The Relative Contributions of Vitamin E, Urate, Ascorbate and Proteins to the Peroxyl Radical-Trapping Antioxidant Activity of Human Blood Plasma,” Biochemica et Biophysica Acta, Vol. 924, 1987, pp. 408-419. http://dx.doi.org/10.1016/0304-4165(87)90155-3

[10] F. B. Pruijn, G. R. M. M. Haenen and A. Bast "Integray between Vitamin E, Glutathione and Dihydrolipoic Acid in Protection against Lipid Peroxidation," Fat Science Technology, Vol. 93, No. 6, 1991, pp. 216-221.

[11] G. L. Ellman and H. Lysko, "Disulfide and Sulfhydryl Compounds in TCA Extracts of Human Blood and Plasma,” Journal of Laboratory and Clinical Medicine, Vol. 70, 1967, pp. 518-527.

[12] T. L. Mc Neil and L. Y. Beck, "Fluorometric Estimation of GSH-OPT,” Analytical Biochemistry, Vol. 22, 1968, pp. 431-441. http://dx.doi.org/10.1016/0003-2697(68)90285-6

[13] L. G. Hansen and W. G. Warwick "A Fluorometric Micromethod for Serum Vitamins A and E,” Technical Bulletin of the Registry of Medical Technologists, Vol. 39, No. 3, 1969, pp. 70-73.

[14] M. A. Bender, A. A. Awa, A. L. Brooks, P. G. Groer, L. Littlefield, C. Pereira, R. J. Preston and B. W. Wachholz, "Current Status of Cytogenetic Procedures to Detect and Quantify Previous Exposures to Radiation," Mutation Research, Vol. 196, 1988, pp. 103-159.

http://dx.doi.org/10.1016/0165-1110(88)90017-6

[15] L. S. Vartyanyan, S. M. Gurevich, A. I. Kozachenko, L. G. Nagler, E. L. Lozovskaya and E. B. Burlakova, "Changes in Superoxide Production Rate and in Superoxide Dismutase and Glutathione Peroxidase Activities in Subcellular Organelles in Mouse Liver under Exposure to Low Doses of Low-Intensity Radiation,” Biokhimiya (Russian), Vol. 65, No. 4, 2000, pp. 522-527.

[16] L. Hagmar, A. Brogger, I. L. Hansteen, S. Heim, B. Hogstedt, K. Linnainma, F. Mitelman, I. Nordenson, et al., "Cancer Risk in Humans Predicted by Increased Levels of Chromosomal Aberration in Lymphocytes: Nordic Study Group on the Health Risk of Chromosome Damage,” Cancer Research, Vol. 54, 1994, pp. 2919-2922. 